\title{
HVMANITAS
}

\section{"Em casa de caranguejo, pele fina é maldição": Filosofia e Sofística em Tutaméia de João Guimarães Rosa}

Autor(es): $\quad$ Augusto, Maria das Graças de Moraes

Publicado por: Faculdade de Letras da Universidade de Coimbra, Instituto de Estudos

URL

persistente: URI:http://hdl.handle.net/10316.2/23175

DOI: DOI:http://dx.doi.org/10.14195/2183-1718_63_34

Accessed : $\quad$ 26-Apr-2023 15:14:28

A navegação consulta e descarregamento dos títulos inseridos nas Bibliotecas Digitais UC Digitalis, UC Pombalina e UC Impactum, pressupõem a aceitação plena e sem reservas dos Termos e Condições de Uso destas Bibliotecas Digitais, disponíveis em https://digitalis.uc.pt/pt-pt/termos.

Conforme exposto nos referidos Termos e Condições de Uso, o descarregamento de títulos de acesso restrito requer uma licença válida de autorização devendo o utilizador aceder ao(s) documento(s) a partir de um endereço de IP da instituição detentora da supramencionada licença.

Ao utilizador é apenas permitido o descarregamento para uso pessoal, pelo que o emprego do(s) título(s) descarregado(s) para outro fim, designadamente comercial, carece de autorização do respetivo autor ou editor da obra.

Na medida em que todas as obras da UC Digitalis se encontram protegidas pelo Código do Direito de Autor e Direitos Conexos e demais legislação aplicável, toda a cópia, parcial ou total, deste documento, nos casos em que é legalmente admitida, deverá conter ou fazer-se acompanhar por este aviso.

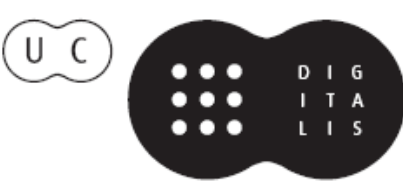


humanitas

Vol. LXIII

2011 


\title{
"EM CASA DE CARANGUEJO, PELE FINA É MALDIÇÃO': FILOSOFIA E SOFÍSTICA EM TUTAMÉIA DE JOÃO GUIMARÃES ROSA
}

\author{
Maria das Graças de Moraes Augusto \\ Instituto de Filosofia e Ciências Sociais \\ Universidade Federal do Rio de Janeiro
}

\section{Resumo}

Tomando por base as afirmações feitas por J. G. Rosa acerca de Platão e do diálogo Fedro - "Vamos ler Platão. Lá está tudo!" e "O livro mais belo: o 'Phèdre' de Platão!" -, nos propomos neste trabalho a realizar uma leitura de Tutaméia, a partir de dois aspecto da prosa dialógica dos diálogos platônicos: o estatuto filosófico do proêmio na composição dos lógoi e o estatuto dos animais na apreensão do conhecimento.

Palavras-Chave: João Guimarães Rosa, Platão, Tutaméia, Atena e Héracles, Tradição Clássica no Brasil.

\section{Abstract}

The aim of this article is based on the affirmations made by J.G. Rosa about Plato and the dialogue Phaedrus - "Let's read Plato. It's all there!" and "The most beautiful book: Plato's 'Phèdre'!" - to propose a reading of Tutaméia based on two aspects of the Platonic dialogic prose: the philosophical status of the proemium in the composition of the logoi and the status of animals in the apprehension of knowledge.

Keywords: João Guimarães Rosa, Plato, Tutaméia, Athena and Heracles, Greek Pottery, Classical Tradition in Brazil. 
Em Ave Palavra, obra póstuma de João Guimarães Rosa, que reúne notas de viagens, anotações diversas, artigos em jornais, contos, poesias, dentre diversas publicações entre 1947 e 1967, encontramos muitas referências hermenêuticas aos gregos, à tradição clássica e, onde os animais estão continuamente referenciados em um contexto gnosiológico. A sentença "em casa de caranguejo, pele fina é maldição" - parafraseando a tradição "casa de ferreiro, espeto de pau" -, faz parte de um conglomerado de sentenças marinhas coligidas sob o título Aquário, publicado na revista Pulso, em 18 de fevereiro de 1967, que nos dá conta de um procedimento metódico que foi sempre caro ao autor: a descrição do mundo e de sua condição à luz dos movimentos e façanhas dos animais. E, nesse sentido, vamos, também, encontrar em um outro texto, Zôo, igualmente publicado em Pulso, em 29 de abril de 1967 (embora uma versão anterior já tivesse sido publicada no jornal $O$ Globo, em 11 de março de 1961), um outro conjunto gnômico onde, entre a pluralidade dos animais expostos em um Zoológico, vamos encontrar uma epistêmica descrição da coruja: "Gláucia me olha, duasmente; toda coruja é bem-assombrada".

Por outro lado, se nos voltarmos para a correspondência e as muitas anotações que acompanharam leituras, viagens e situações diversas ao longo da vida de Guimarães Rosa, veremos que a presença dos diálogos platônicos, como fonte de influência e modelo de trabalho intelectual, é marcadamente significativa.

A anotação feita à mão em seu exemplar do Fedro, de Platão, guardado nos arquivos do IEB da Universidade de São Paulo - "O livro mais belo: o 'Phèdre' de Platão! ..." -, e a observação feita em carta para Azeredo da Silveira, em 9 de fevereiro de 1956, afirmando que a "política é o demônio, suas obras, sua desordem. Vamos ler Platão. Lá está tudo!”, são muito mais do que uma simples menção ao filósofo grego, mas, a indicação de sua presença constante no mundo dos buritis e das veredas, ${ }^{1}$ e que estão ratificadas em muitas outras anotações:

${ }^{1}$ Cf. Carta a Azeredo da Silveira pertencente ao Arquivo Paulo Rónai, em Nova Friburgo, Sítio Pois é. Gostaria de mencionar aqui meus agradecimentos a Ana Luiza Martins Costa pelo acesso a todo o seu imenso arquivo sobre Guimarães Rosa, a indicação constante de textos que remetem ao contexto grego, e, platônico em especial, e de bibliografia complementar, bem como, uma interlocução constante que faz do trabalho intelectual um suporte efetivo da philía. 
"Os grandes livros - e tenham os bois logo nomes: a Bíblia, a Ilíada, a Odisséia, a Divina Comédia, todo o Shakespeare, todo o Goethe, todo Platão principalmente, e todo Camões, e fico nos que freqüento (mais) - são a leitura mais atual, mais moderna e mais quotidianamente aproveitável que possa haver." (JGR, “Caixa 21, Doc. 1(37) 9 envelopes. AGR/IEB/USP. grifos nossos)

[...] E o poeta aprende a ver as coisas em estado nascente - que é sábia maneira de desver o mesmismo estouvado da realidade aparente. Convém reler o apólogo das sombras na parede da caverna, na "República" de Platão). (JGR, “Cx 21, 1 (37) - Env. 3/9 (4). AGR/IEB/USP)

E eu mesmo fiquei espantado de ver, a posteriori, como as novelas, umas mais, outras menos, desenvolvem temas que poderiam filiar-se, de algum modo aos "Diálogos" [...]. Quero ficar com o Tao [...] , com Platão, com Plotino, com Bergson, com Berdiaeff - com Cristo, principalmente. (BIZZARRI, 2003:90.)

Desse modo, uma leitura da estrutura gráfica dos contos e dos prefácios incluídos nas "terceiras estórias" de Tutaméia à luz dos diálogos platônicos, nos dá uma compreensão mais larga do estatuto clássico da obra de João Guimarães Rosa, conformada muito além das epígrafes e das notas de péde-página, ${ }^{2}$ na qual encontraremos, claramente delimitados, dois aspectos da prosa dialógica platônica: o estatuto filosófico dos proêmios, no qual estão inseridos os "4 Prefácios", e, o estatuto dos animais como modo de apreensão do conhecimento (Frère, 1998:5-8), que será analisado em função das efígies da coruja e do caranguejo, apostas ao final dos prefácios e dos contos. ${ }^{3}$

${ }^{2}$ Por exemplo, as citações em grego no conto 'Cara-de-Bronze', em Corpo de Baile; a epígrafe do Górgias, de Platão, no conto 'Páramo', em Estas estórias, além das diversas referências nos 'Prefácios' de Tutaméia.

${ }^{3}$ A edição de Tutaméia pela Editora Nova Fronteira constitui-se num conjunto de equívocos que degradaram a obra de Guimarães Rosa: a alteração integral da relação dos prefácios e dos contos a partir do uso do grifo e dos romanos e a eliminação das efígies da coruja e do caranguejo ao final dos prefácios e contos, é equívoco não só lamentável, mas, sobretudo, alteração abusiva e comprometedora da integralidade da obra e dos objetivos de Rosa, a edição de Tutaméia pela Nova Fronteira, atendendo aos apelos da modernidade, tornou o livro "ilegível", vazio 


\section{A função proemial dos Prefácios em Tutaméia.}

O que teria movido JGR a entremear quatro prefácios entre os quarenta contos de Tutaméia?

Um primeiro indício pode estar na narrativa reconstituída por Benedito Nunes de seu encontro com Guimarães Rosa, em fevereiro de 1967, no Palácio do Itamaraty, quando indaga ao escritor acerca das duas citações de Platão, em grego, nas notas incluídas no conto "Cara-de-Bronze", em Corpo de Baile (Rosa, 1956:610):

- De que diálogo de Platão são essas palavras?

- Não seria capaz de lhe dizer agora. Vou lendo os filósofos e deles transcrevo nos meus cadernos o que me interessa. Isso, depois, como tudo quanto recolho dos livros e da boca das pessoas, poderá fazer parte de uma estória.

[...] Nada tenho de erudito. Absorvo. Por isso é difícil saber, quando me voltam à memória, onde fui buscar, exatamente, o trecho ou a passagem que já foram por mim incorporados.

[...] Aquelas palavras a que você se referiu, explicou-me Guimarães Rosa, são mesmo do filósofo grego, tal como registro no meu conto. Posso, no entanto, contrafazer o autor do Banquete. Os especialistas, historiadores da filosofia, não serão capazes de descobrir as citações fictícias. E dificilmente acertam com a fonte se lhes apresento as que são verdadeiras. (Nunes, 1968: $1-3)^{4}$

Afeito aos jogos de linguagem, brincadeiras e adivinhas, Rosa, ao falar de sua contrafação ao autor do Banquete, poderia estar mais uma vez "enganando" seu interlocutor, desviando sua atenção para esse diálogo, pois as duas referidas citações, se forem rastreadas na obra de Platão, serão encontradas em outros diálogos: a primeira delas, "Tà sesêmasména kaì tà asémanta", 5 é retirada de Leis, 954a-8, e a segunda, "Hai prókheiroi

de seus significados essenciais pela violação imoral da obra de Guimarães Rosa.

${ }^{4}$ Em artigo publicado, em 2006, nos Cadernos de Literatura Brasileira, do Instituto Moreira Salles, dedicado a Guimarães Rosa, Benedito Nunes retoma essa narrativa - com ligeiras diferenças daquela publicada em 1968 pelo Suplemento Literário do jornal Minas Gerais -, onde salienta o "aproveitamento lúdico da filosofia do escritor". (Nunes, 2006 : 241)

${ }^{5}$ Cito aqui o passo 954a-8 das Leis, tal como aparece na nota da 1. ${ }^{a}$ edição de Corpo de Baile. 
hédonai", do Filebo, 45a-4, ${ }^{6}$ embora esta não seja uma citação exata, o que parece ser, ainda, não só a contrafação de Rosa em Platão, mas, também, parte de suas intenções hermenêuticas, pois o trecho por ele citado pertence a uma pergunta colocada por Sócrates a Protarco: 'Âr' oûn, hai prókheiroí ge haíper kaì mégistai tôn hedonôn, hò légomen pollákis, hai perì tò sộmá eisin haûtai;" (Os prazeres mais imediatos e maiores não são aqueles, como se diz muitas vezes, próprios do corpo?). ${ }^{7}$ Apresentada no Cara-deBronze de modo distinto do original platônico, a citação tem o sabor de ser uma resposta de JGR à pergunta feita por Sócrates no diálogo: os prazeres do corpo são prókheiroi!

A citação, retirada do livro XII das Leis, possui vários aspectos que nos permitem uma compreensão platônica dos prefácios à luz da função que o proêmio, como elemento componente tanto da prosa, quanto da poesia, cumpre, não só na elaboração das leis, mas, também, no fato de no livro XII, assim como o tema do proêmio, as leis estritas nele fundamentadas, dizerem respeito à vida da cidade em suas relações com o mundo exterior e com a propriedade pública, privada e às penas relativas às infrações, bem como, às normas referentes à vida guerreira, temas que, não parece difícil de aceitarmos, fascinaria intelectualmente e existencialmente o autor de Tutaméia.

Fascínio que uma primeira vista d'olhos no livro XII das Leis parece facilmente confirmar e justificar o interesse que o último diálogo escrito por Platão possa ter despertado em JGR: a honestidade dos arautos e embaixadores em relação à cidade (941a-942a); o proêmio e as leis relativas à vida guerreira (942b-945a); a formação do Conselho reparador das

${ }^{6}$ Cito aqui a passagem tal como aparece na nota da $1{ }^{\text {a }}$ edição de Corpo de Baile, no original platônico temos: "[...] hai prókheiroí [...] tôn he donôn , [...]."

${ }^{7}$ A citação feita por Rosa modifica parcialmente o que diz o texto original, transformando-o, a nosso ver, em um comentário platônico ao contexto do conto Cara-de-Bronze, e que lido no texto original do Filebo, torna mais claro e mais largo os objetivos do referido conto e da obra em que está inserido, o Corpo de Baile: “Âr' oûn, hai prókheiroí ge aíper kaì mégistai tôn hedonôn, hò légomen pollákis, hai perì tò soma eisin haûtai?" [Os prazeres mais imediatos e maiores não são aqueles, como se diz muitas vezes, próprios do corpo?] Cf. Filebo, 45a-45. A pergunta, colocada por Sócrates a Filebo e Protarco no diálogo Filebo, acerca da "boa vida", se é aquela que se funda no prazer (hedoné ) ou a que se estrutura na compreensão (phrónesis), não deixa de ser um dos grandes temas de Cara-deBronze. 
ações injustas (945b-958c); as relações exteriores da cidade: o comércio, a regulamentação das viagens, as "espécies" de visitantes estrangeiros que serão recebidos na cidade, cauções, dívidas, propriedades duvidosas, roubo e corrupção, organização de processos e tribunais, e, por fim, o controverso Conselho Noturno que, à semelhança de Láquesis, Cloto e Átropo, ao emprestarem a vida humana a força irreversível da torsão do fio, deverá, além de cuidar da saúde e da salvação do corpo, inspirar na psykhé o princípio da conservação das leis (960c-d). Temas, portanto, muito próximos dos contos e romances, mas, muitas vezes explicitados também em cartas a diversos destinatários.

Desse modo, quando retomamos o contexto do passo 954a-8, verificamos o uso do particípio perfeito, tà sesemasména, do verbo semaíno, em oposição à tà asémanta, às coisas "seladas" e às coisas "não-seladas", direcionando a busca que se faz de algo perdido,

[...] se alguém quiser dar busca nalguma casa, terá de apresentar-se nи oи apenas de túnica sem cintura, depois de jurar pelas divindades designadas por lei que espera encontrar nessa revista o objeto perdido. O dono da casa lha franqueará, permitindo-lhe examinar tudo, tanto o que estiver selado como o que não estiver (ho dè parekhéto tèn oikían, tà te sesêmasména kaì tà asémanta, phorân). Quem não consentir na busca, será intimado judicialmente pelo queixoso, depois de avaliar este o objeto perdido, e, se for positivado o crime, o culpado pagará o dobro da avaliação. Estando ausente o dono da casa, os outros moradores deixarão revistar os objetos não selados, colocando seu selo o interessado por cima dos que encontrar, e entregará os objetos a alguém de sua confiança, pelo prazo de cinco dias. Se a ausência daquele se prolongar, o denunciante far-se-á acompanhar dos astínomos para, com eles, realizar a busca, e desatará até mesmo o que estiver selado, depois do que tornará selar tudo na presença dos astínomos e do pessoal da casa. $(\mathrm{Lg}, 954 \mathrm{a})^{8}$

Poderíamos, então, inferir que essa "busca" será retomada por Rosa em seu valor metafísico e gnosiológico: a busca do Grivo para o fazendeiro Cara-de-Bronze metaforizando a busca como o sentido da existência,

${ }^{8}$ Cito aqui a tradução de Carlos Alberto Nunes, publicada pela Editora da Universidade Federal do Pará, em 1980, com modificações. Todas as demais citações das Leis serão retiradas da referida tradução. 
descrita também no Fedro, 250b-c, a partir da contemplação da beleza, e onde temos uma outra ocorrência do termo asemantós:

Porém, não sabem que nem a justiça, nem a temperança, nem tudo o que alma tem em grande estima, têm aqui [no sensível] a mesma claridade, $e$, com órgãos turvos e, por isso mesmo, com assaz dificuldade, é que as poucas pessoas que se aproximam das imagens conseguem contemplar o gênero do modelo original. A beleza era muito fácil de ver por causa do seu brilho peculiar quando, no séquito de Zeus, tomando parte no coro dos bemaventurados e os demais no de outra divindade, gozávamos do espetáculo dessa visão admirável e, iniciados nesse mistério que, com toda a justiça, pode ser denominado sacratíssimo, e que celebrávamos na plenitude da perfeição e livres dos males que nos alcançam no tempo ulterior, fomos admitidos a contemplar sob a luz mais pura aparições íntegras, simples, imutáveis, pois, sendo puros não tínhamos o selo [en augê(i) katharâ(i) katharoì óntes kaì asémantoi] deste cárcere de morte que com o nome de corpo carregamos conosco e no qual estamos aprisionados como a ostra à sua concha. (Phdr., 250b-c, grifos nossos) ${ }^{9}$

Ou, melhor dizendo, como o fulcro da boa e bela escrita que permanece como "selo" da busca metafísica do sentido das coisas que são e das que não-são, numa continuidade de significados que nos levaria, nos termos rosianos, de Homero a Platão, de Platão a Proust, tal como

${ }^{9}$ A tradução da passagem do Fedro é também de Carlos Alberto Nunes, com modificações. Aqui seria interessante retomar o que diz Rosa sobre a Beleza e a luz da Itália: "Depois, à medida que se vem para o sul, o fogo do céu depura e decanta a Luz: por cima dos dois vulcões, em Nápoles e na Sicília, ela ocupa uma serenidade despótica, um azul às vezes cruelmente desepidermizado..." Parece exagero de poesia? Pois o poder e a realidade daquela luz ainda ficam além de tanto entusiasmo." Carta aos pais, escrita em Paris, com data de 3 de setembro de 1950.

A influência do Fedro, e o reconhecimento de que ele é o "mais belo livro!" talvez possa estar nessa conjuntura onde a ambigüidade da iniciação mistérica sugerida por Platão na passagem citada deste diálogo, atrelada à visão das idéias como próprio ao conhecimento filosófico, possam ter norteado a escrita de Rosa posteriormente às suas viagens ao sul da Itália. De Corpo de Baile à Tutaméia não teríamos o trajeto confluente e antagônico, de Homero a Platão na elaboração dos romances, novelas e contos de JGR? 
enunciado em Cara-de-Bronze pelo plurilíngüe eu do vaqueiro Moimeichego, "Amigo, cada um está sempre procurando todas as pessoas deste mundo".

Nesse contexto, então, parece-nos extremamente razoável a inferência de que o médico, o diplomata e o escritor JGR tenha lido com singular atenção os diálogos de Platão, e que tenha retirado das Leis sua concepção de "prefácio" tal como utilizado em Tutaméia.

Mas, em que termos fala Platão nas Leis dos proêmios, cuja concepção teria sido retomada por JGR?

No livro IV deste diálogo, após propor a seus interlocutores, Clínias e Megillo, construírem com o lógos uma pólis que sirva de molde para a colônia que Clínias irá fundar, o estrangeiro de Atenas, tendo delimitado os princípios relativos ao contexto geográfico, físico e populacional da cidade, passará às questões que envolvem as relações entre a politeía e os nómoi, a forma de governo e as leis que deverão ordená-la.

O ponto de partida para a elaboração dos nómoi e da escolha da politeía estará atrelado ao reconhecimento de que a legislação (nomothesía) e a fundação de cidades é o meio mais eficaz para se criar homens virtuosos (pròs aretẹn andrônn) (Leis, 708b-d) E, se partirmos desse princípio, veremos que nunca nenhum homem fez leis, ao contrário, elas são resultado do acaso e de uma pluralidade de acontecimentos que desabam sobre eles: uma guerra, que destruindo a politeía modifica as leis; a pobreza, hostil às necessidades; as doenças que impõem inovações, como por exemplo, quando há pestes ou quando por muito tempo as estações são ingratas. Os fazeres humanos, os tà anthrópina prágmata, diante de tais vicissitudes, dependem, sobretudo da týkhe, do acaso, e, por isso nenhum mortal elaborou, de fato, leis ( $L g ., 709 a-709 b-2)$.

Mas, se alguém afirmar que é o divino que tudo conduz, e que é o deus, o acaso e a oportunidade que conduzem todas as coisas humanas deveríamos "abrandar a aspereza da proposição", acrescentando-lhe um terceiro elemento, a tékhne, pois, em ocasiões dificultosas, como em uma tempestade, a oportunidade da arte do piloto é muito mais vantajosa do que a sua falta ( $L g$., 709c-1-3). E, se assim ocorre em tudo o mais, no caso de uma cidade que reúna as condições que possibilitem a felicidade de seu seus cidadãos, necessário será que a ela acrescentemos um governante jovem e naturalmente dotado de boa memória, facilidade de aprender, coragem, magnanimidade e que tenha, presente em sua alma, a dikaiosýn $\underline{e}$ que acompanha cada uma das "partes da aretế" e que a ele se junte "um 
nomothetés que tenha a verdade nele mesmo", o que lhe permitirá, assim, exercer retamente a "arte da nomothesía" ( $L g ., 709 \mathrm{c})$.

Ora, se todas essas circunstâncias se consubstanciarem simultaneamente, não só a cidade terá todas as condições para "agir bem”, mas, também, a coalescência entre a politeía e os nómoi poderá ser estabelecida a partir do reconhecimento de que são legítimas apenas as leis e as formas de governo que forem estabelecidas a partir do interesse comum de toda a cidade $(L g, 715 b)$, sendo, portanto, inadequada a atribuição do nome de politeía e nómoi àqueles governos e às leis que lhes estão atreladas, fundados estritamente no interesse dos governantes ( $\mathrm{Lg} ., 715 \mathrm{c})$. Portanto, a função do nomothetés será a de forjar leis que sejam capazes de bem persuadir aos homens de que a areté só se estabelece na cidade sob a ação da politeía, devendo, por isso, valer-se de um procedimento contrário ao do poeta, uma vez que este, segundo um antigo mythos, quando se instala no tripé das Musas, não é mais senhor de sua phrónesis, e, de modo análogo a uma fonte, deixa correr livremente tudo que lhe advém, sendo exatamente por isso que sua arte não passa de mera mímesis, sendo forçado, quando os homens que ele imita tenham sentimentos contrários entre si, a contradizerse, sem saber qual das suas falas é a verdadeira (Lg.,719c-720a). Inversamente, o legislador só poderá produzir um único lógos acerca do tema sobre o qual elabora sua lei, pois, quanto aos deveres dos cidadãos cuidados com os descendentes, amigos e concidadãos, as relações de hospitalidade determinadas pelos deuses e as obrigações sociais que precisam ser atendidas no convívio geral -, que devem ser regulados por prescrições legais que "purificam e embelezam a vida", compete à lei determinar detalhadamente cada um deles, fazendo com que venham a ser obedecidos seja por meio da persuasão, seja por recurso à violência ou à justiça, se por ventura mostrarem-se refratários aos lógoi dos nómoi ( $L g$., 718a-b).

Assim, para que os nómoi possam ser produtores de beleza, o nomothetés deverá recorrer a um procedimento semelhante ao dos médicos, que são de duas espécies: o médico escravo, que cuida de homens escravos; e o médico livre, que cuida também de homens livres, quando solicitados a produzir a cura do modo mais brando possível. O primeiro, quando cuida de seus doentes, não comenta as doenças, nem ouve explicações de seus pacientes, agindo como tirano, a partir do que empiricamente aprenderam, sem demorar-se, e passando a seguir aos outros doentes; o segundo, ao contrário, e por cuidar também de homens livres, examina os doentes, 
acompanha-os desde o início dos males conforme a natureza, comunicando suas impressões ao doente e a seus amigos, enquanto amplia seus conhecimentos, esclarece o paciente na medida do possível, só prescrevendo alguma coisa depois de tê-lo persuadido da eficácia da dieta, conseguindo, assim, com a ajuda da persuasão, acalmar o doente e reconduzi-lo à saúde $(L g, 720 \mathrm{c}-\mathrm{d})$.

No caso do legislador, ele poderá valer-se de duas espécies de enunciados para determinar a lei: [i] o simples (tò haplệ), que pode ser formulado como no seguinte exemplo,

(...) para casar é necessário que se tenha de trinta a trinta e cinco anos e quem não cumprir esse dispositivo sofrerá pena de multa e atimía, sendo a multa de diferentes importes e a privação dos direitos civis e políticos, de diversas extensões ( $L g ., 721 \mathrm{~b})$,

limitando-se, portanto, a ameaçar e [ii] o duplo (tò diplê), ao qual acrescentar-se-á a fundamentação da lei:

Casa-se quem tiver de trinta a trinta cinco anos, tomando-se em consideração que, por natureza, o gênero humano participa de certa imortalidade, que todos instintivamente aspiram. Ora, de certo modo o gênero humano se desenvolve em íntima correlação com o tempo, que ele acompanha e acompanhará até o fim, o que é sua maneira de ser imortal, com deixar após si os filhos de seus filhos, sempre uno e o mesmo, participando, pela geração, da imortalidade. (Lg., 721b-c)

ou seja, ele persuade e ameaça.

Entretanto, no que diz respeito à lei, a fórmula dupla parece não só superior à simples, mas, até agora, nenhum legislador foi capaz de lembrarse que dispõe de duas possibilidades para estabelecer a obediência às leis, a persuasão e a força, tendo recorrido apenas a uma das possibilidades, servindo-se apenas da força, daí a necessidade de introdução de um terceiro elemento, até então nunca considerado pelos legisladores e que será assim definido pelo estrangeiro de Atenas:

O fato é que, desde que começamos a conversar e a manhã cedeu o lugar ao meio-dia, alcançamos este aprazível pouso sem falar em outra coisa a não ser leis; no entanto, somente agora principiamos a entrar no assunto 
propriamente dito, pois tudo que ficou para trás constitui apenas o proêmio às leis. E porque me exprimo desse modo? Pelo desejo de acrescentar a observação de que a todo discurso, e tudo em que a voz participa comportam um prồmio, por assim dizer, uma espécie de exercício preparatório que vale como exórdio de grande vantagem para o que se quer desenvolver. (Lg., $722 \mathrm{c}-\mathrm{d}$, grifos nossos)

A seguir, a explicação acerca da utilidade do proêmio será dada pelo Ateniense a partir da analogia do nómos, gênero musical, com o nómos, gênero político. Ao contrário dos nómoi poéticos nos quais as odes acompanhadas pela cítara, principiam sempre por um "proêmio maravilhosamente trabalhado", o "nómos politikós", que conforma as leis que efetivamente são, não tiveram ainda nenhum nomothetés que lhes elaborasse um proêmio, como se, por natureza não devessem existir (Lg., 722e). A lei pura, sem nenhuma mistura, denominada tirânica, por analogia com a ação do médico escravo, não age via persuasão, enquanto, a lei que recebeu o qualificativo de persuasiva corresponde à dýnamis proemial do nómos politikós, pois para que o cidadão, a quem a lei é destinada, receba com simpatia e benevolência a prescrição que é a própria lei, devemos antes apresentar-lhe como dýnamis desse lógos o proêmio que produzirá a persuasão, condição para que a obediência à lei seja a conquista da excelência, da areté.

Daí a necessidade de que o legislador aponha às leis um proêmio, o "que as deixará tanto mais diferentes entre si como diferem os dois métodos mencionados a pouco", embora, tal como nem todos os cantos e discursos necessitem de um proêmio, não será necessário proemiar todas as leis, não porque cada uma não possa ter o seu proêmio, mas não há necessidade de proemiar a todas, a decisão, em cada caso particular, ficará a cargo do legislador, do músico ou do orador ( $L g ., 723 \mathrm{c}-\mathrm{d})$.

A teoria dos proêmios, apresentada nas Leis, parece ser já a ordenação de uma prática instituída em diálogos como a República, o Fedro, o Fédon e o Timeu, para falarmos em diálogos que Rosa não só leu, mas que, de uma forma ou de outra, menciona claramente em seus contos e romances. Nesse sentido, podemos apontar para toda uma configuração dos proêmios que teria instigado João Guimarães Rosa - o médico e o diplomata - a exercitar a tese exposta nas Leis: o valor analógico entre a arte da medicina e a arte do legislador, o fato de ambas serem vistas por Platão como "tékhne"; a formulação clara nas Leis de que à nomothesía é atribuído o 
valor positivo da escritura, as leis devem ser "escritas" e para tal, a discussão exposta por Platão no Fedro acerca da "boa escritura", de como se deve escrever para que a escritura seja um bem, torna-se crucial.

Por outro lado, o proêmio é um elemento comum à prosa e à poesia. É parte do discurso retórico, tal como descrito no Fedro, 266d7-9, e, é um elemento comum aos gêneros líricos, e aqui não seria inoportuno lembrar o "proêmio a Apolo" mencionado no Fédon como um modo encontrado por Sócrates, em sua espera pela cicuta, de praticar a mousiké, produzindo, portanto, um hino em homenagem ao deus. Sua função, nos diálogos platônicos, deve ser vista como exemplarmente filosófica, tal como fica demonstrado na República, diálogo mais de uma vez mencionado por Guimarães Rosa em Tutaméia (cf. por exemplo, Rosa, 1967:4,8), onde temos três proêmios intercalados ao longo do diálogo: um proêmio à dikaiosýne, que é o livro I $(R ., 357 \mathrm{a}-1-2)$, um proêmio à politeía, que é composto pelos livros II, III e IV $(R ., 432 \mathrm{e}-8)$, e, um proêmio à filosofia, elaborado ao longo dos livros V, VI e VII (R., 531d-8-10; 532d-7). Nesse sentido, o proêmio, portanto, parece ser para Platão o signo da "arte da escritura", pois exige do filósofo a visão clara e reta dos temas que o compõe. No caso das Leis, onde estas cumprem a função do rei-filósofo na República, só um nomothetés-filósofo poderia redigi-los, uma vez que eles supõem uma condição essencial: o conhecimento das idéias.

Desse modo, os prefácios intercalados aos contos de Tutaméia parecem conter o desafio da elaboração de uma prosa platonizante em meio aos grandes temas rosianos: a imortalidade da alma, o confronto entre bem e mal em um cosmo modelado por um demiurgo, a memória como receptáculo da coalescência entre mythos e lógos, a expectativa dialógica da existência sempre refeita pela experiência da memória na escrita, e na sua completude expressa pelo lógos como "imagem" coordenada pelo valor poético a elas atrelados. Nos prefácios, acreditamos, temos a justificação dos contos, da narrativa ao estilo, do texto e do contexto, da variação entre prosa e poesia perseguida por Rosa, o valor ontológico e metafísico dos discursos em sua condição mimética que consigna toda a "arte de bem escrever".

Se nos ativermos aos quatro prefácios de Tutaméia, admitindo que, tal como as leis do estrangeiro de Atenas, estarão interligadas por seus proêmios, eles contêm a fundamentação dos contos em que estão intercalados, veremos também que a concepção platônica da "arte de escrever bem" estará lá representada em seu conflito maior com a retórica e com a poesia. 


\subsection{Do grifo às idéias: o texto e o contexto dos Prefácios}

Os quarenta contos de Tutaméia estão apresentados, em todas as edições da José Olympio, ${ }^{10}$ em dois sumários com disposição gráfica e conteúdos ligeiramente diferentes.

O primeiro sumário, que vem logo a seguir à folha-de-rosto, contém o título da obra, em caixa alta - TUTAMÉIA - acrescido do subtítulo em versalete (TERCEIRAS ESTÓRIAS), logo abaixo do título; e, a seguir, a epígrafe, retirada da obra de Schopenhauer, indicando a "paciência" necessária à primeira leitura de um texto e apontando para os ganhos que obteremos com uma segunda leitura, pois com ela "muita coisa, ou tudo, se entenderá sob luz inteiramente outra" (apud., Rosa, 1967:f.12), seguindose a disposição dos títulos dos prefácios e contos em coluna dupla, sequiencial de paginação, sem nenhuma indicação precisa da diferença entre eles, além da apresentação tipográfica: os títulos dos prefácios aparecem em grifo; os contos em tipos romanos.

O segundo sumário, que aparece no final do volume, antecedendo o colofón no verso da folha, com o subtítulo do primeiro como título TERCEIRAS ESTÓRIAS -, e o título como subtítulo em versalete (TUTAMÉIA) -, e logo abaixo deste, talvez, explicitado pela necessidade da segunda leitura, será acrescido da designação "Índice de releitura". A epígrafe, embora distinta da anterior, será também retirada da obra de Schopenhauer, trazendo indicações acerca do modo de leitura da totalidade de um texto, uma vez que "a construção, orgânica e não emendada, do conjunto, terá feito necessário por vezes ler-se duas vezes a mesma passagem" (apud., Rosa, 1967:193), e será a partir da epígrafe que os textos que compõem as Terceiras Estórias de Tutaméia estarão, agora, indexados em prefácios e contos, impressos em caixa alta, em romanos, seguidos de dois pontos, e, tendo abaixo os títulos de cada um deles, sendo que os títulos dos prefácios estarão também impressos em grifo, e o título dos contos em tipos romanos, com cada um dos conjuntos separados, primeiro o conjunto dos prefácios, e, abaixo deste, o conjunto dos contos. Cada um

${ }^{10} \mathrm{O}$ volume de Tutaméia citado ao longo de nosso texto será sempre o da $1^{\mathrm{a}}$. edição, publicada no Rio de Janeiro, em 1967, pela Livraria José Olympio Editora, com capa de Luís Jardim. JGR faleceu em novembro de 1967, essa é a edição que foi produzida com sua autorização e de acordo com suas "intervenções gráficas", como é confirmado pela José Olympio na obra Em memória de João Guimarães Rosa, publicada em 1968. 
dos conjuntos está indexado em ordem crescente de paginação, e exposto em duas colunas.

Ora, a organização dos sumários e o estatuto gráfico do texto parecem já apontar para um acordo estreito entre as idéias e as imagens que compõem o livro de João Guimarães Rosa. No que tange aos sumários, poderíamos lembrar que a escolha de seu padrão tipográfico será inteiramente respeitada no corpo da obra: os prefácios serão sempre impressos com grifo, seja nos títulos indexados nos dois sumários, seja em seu conteúdo no corpo do texto. Escolha aleatória ou integração do "livro" ao contexto do humanismo renascentista? E aqui não seria inoportuno lembrar que o grifo tem origem na escrita epistolar humanista, e parece ser o tipo que convém aos prefácios se seguirmos os critérios estabelecidos por Jean Tschichold, ao falar da "diferenciação tipográfica”: “... num prefácio, o grifo é tipo básico, utilizase o romano para destaque, não o grifo interespacejado." (Tschichold, 2007:146) Aliás, o projeto gráfico de Tutaméia parece ter sido composto em consonância com as teorias de Tschichold, publicadas na Alemanha, a partir do final da década de 40, com sua pequena história sobre grifos, versaletes e aspas, fundamentam a disposição gráfica de Tutaméia, e, se admitirmos que os animais, têm, no texto de Rosa e Platão uma função gnosiológica, veremos que a inclusão das efígies da coruja e do caranguejo ao final de vários contos e de dois dos Prefácios, Hipotrélico e Sobre a escova e a dúvida, completam, por um lado, a tese de Tschichold de que o "estilo tipográfico é determinado por nossa maneira de viver e por nossas condições de trabalho" (Tschichold, 2007:43), e, por outro, a coalescência entre o substrato de uma arte, de uma tékhne, e o resultado de sua ação, de seu érgon.

Nesse sentido, o texto da orelha do segundo volume da $1^{\text {a }}$. edição de Corpo de Baile, de 1956, certamente composta pelo próprio Rosa, nos fala de sua preocupação, e da José Olympio, com o projeto gráfico do texto e da relação entre Rosa e Poty, o ilustrador de Corpo de Baile:

Na história de um livro, há pelo menos cinco figuras indispensáveis, que somam esforços para que as palavras apareçam no papel ordenadas diante do leitor numa prevista clausura gráfica. $O$ autor, o editor, o ilustrador, o impressor, o revisor. Desses cinco elementos, o ilustrador, aquele que nos abre a primeira porta para um novo mundo, tem sido na história desta Casa uma tradição de felizes encontros com os autores, às vezes até em associações que não se admitiriam rompidas, tal a identidade de objetivos e 
"Em casa de caranguejo, pele fina é maldição": Filosofia

e Sofística em Tutaméia de João Guimarães Rosa

de mútua compreensão na órbita das artes, da literatura e do desenho ou da pintura. [...] Indicado pela Casa a Guimarães Rosa para executar as capas de seu novo livro, [...] Poty foi inicialmente apresentado, com as formalidade de estilo (ou sem elas?) ao buriti, a palmeira totêmica de Guimarães Rosa. visitando os espécimes existente no Jardim Botânico. [...] E aí começaram as dificuldades, porque o próprio Guimarães Rosa, pedindo um esboço, recebia logo no outro dia quatro ou cinco modelos de capa, cada qual mais "agarrante", mais coberta de visgo para o descuidado analista.

Como escolher? Guimarães Rosa não o sabia e o céu indiferente não se apiedava de suas dúvidas, de seus olhos deslumbrados por todos aqueles motivos tão próximos do coração que despertava ao vento dos gerais soprando entre aquelas figuras realizadas de cores e linhas. Afinal, porque entre o livro e a capa que agora o cinge havia uma identidade que o escritor descobria com lucidez e ternura, eis que um e outra animavam-se do profuso e do variado, os leitores contemplam neste momento a vencedora de um prélio difícil e marcado pela insônia. (Corpo de Baile. v. 2, 1956, grifos nossos)

Em uma de suas cartas a Eduardo Bizzarri, tradutor italiano de Corpo de Baile, Rosa indicar-lhe-á, como modo de "apreciar mais sua tradução", o acréscimo de alguns "ornatos gráficos":

“... talvez Você passasse a apreciar mais sua tradução se lhe aplicasse alguns “ornatos gráficos”. Por exemplo: pôr CANZONE DI FESTA assim em versais ou versaletes; pôr, alternadamente, as alcunhas em grifo e em normal (entrariam em grifo Ciccio Strazia-Violino... Ciccio del Nord ...Ciccio della Rita) e idem para as designações de lugar; ...frazione del-l'Alzaia... Valle dell'Alzaia)." Bizzarri, 2003:139)

A importância do "ilustrador" e "a identidade de objetivos e de mútua compreensão na órbita das artes, da literatura e do desenho ou da pintura”, ou seja, entre o autor e a concepção gráfica de sua obra, confirmadas pela Livraria José Olympio Editora, em Breve explicação a propósito deste livro, no volume publicado em homenagem ao escritor em 1968, parece ser magistral no caso de Tutaméia, pois, os gregos e o renascimento estarão presentes, acreditamos, a partir de sua decisão de acrescentar aos contos e prefácios desenhos de animais, a coruja e o caranguejo (figs. 1 e 2), 
O desenho de bico de pena que reproduzimos acima foi executado por Luís Jardim especialmente para a $1^{a}$. edição de Tutaméia a mando do próprio Rosa. (Em memória de JGR, 1968:f.4)

Guimarães Rosa logo começou a participar da preparação editorial do opúsculo, como acontecia sempre que preparávamos edição ou reedição de qualquer livro seu - "intervenções gráficas" que acatávamos: ele sugeria o feitio das capas [...], rabiscava vinhetas ou ornatos (foram de sua escolha os cul-de-lampes (sic) de Tutaméia feitos por Luís Jardim: um deles, desenho de um caranguejo, é o símbolo do signo zodiacal do escritor [...]. Trouxe sempre as "orelhas"para seus livros. (Em memória de JGR, 1968:8)

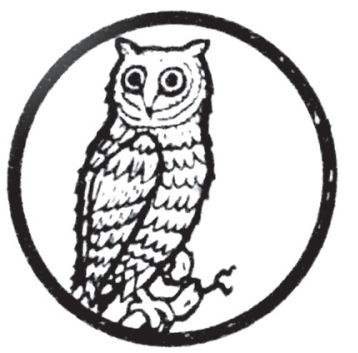

Fig.1. Cul-de-lampe

Desenho de Luís Jardim para

Tutaméia com a "intervenção gráfica” de JGR

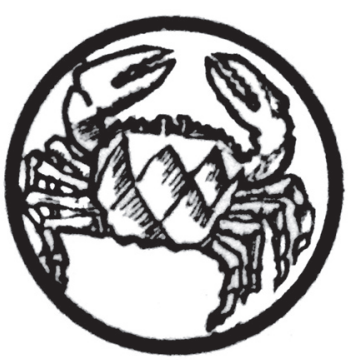

Fig. 2. Cul-de-lampe

Desenho de Luís Jardim para

Tutaméia com a "intervenção gráfica" de JGR

para cumprirem função hermenêutica aos seus conteúdos, explorando, assim, o valor dos animais que compunham os escudos dos hoplitas pintados na cerâmica grega e que Rosa certamente conheceu em suas andanças pelos diferentes museus que visitou ${ }^{11}$, tal como nos diz, em carta aos pais, datada de 3 de setembro de 1950:

O Museu de Nápoles com as maravilhas da arte grega (...) O célebre aquário de Nápoles riquíssimo em espécies marinhas do Golfo. Uma série de lugares que nem nos sonhos poderiam ser mais belos, entre eles Posílipo - antiga

11 Nas obras pertencentes a JGR guardadas no IEB/USP, encontramos catálogos e publicações de vários museus europeus: Musée National de Náples, les collections archeologiques; Musée Nissim de Comondo e Musée Rodin, em Paris; Chefs d'Oeuvre des Musées de Berlin, Chefs d'Oeuvre de la Pincothèque de Munich, Chefs d'Oeuvre récupérées en Allemagne. 
colônia dos gregos, que, ante tamanha maravilha deram-lhe esse nome, que queria dizer: "cessação da tristeza".

E que já estava em seu horizonte intelectual e visual desde 1936, se levarmos em conta o testemunho do poema Caranguejo, incluído no volume Magma, premiado com o primeiro lugar no Concurso Literário da Academia Brasileira de Letras (Martins-Costa, 2006:15), e onde temos não só a referência zodiacal sublinhada por José Olympio, mas, sobretudo, a menção ao escudo do hoplita grego:

Caranguejo feiíssimo, monstruoso, que te arrastas na areia como a miniatura de um tanque de guerra ... Gosto de ti caranguejo,

Câncer meu padrinho nas folhinhas, pois nasci sob as bênçãos do teu signo zodiacal ...

Teu par de puãs cirúrgicas oscila

à frente do escudo lamacento

de velho hoplita.

[...]

És forte, e ao menor risco te escondes

na carapaça bronca, como fazem os seres evoluídos, misantropos retraídos:

o filósofo, o asceta, o cágado, o ouriço, o caracol ...

Caranguejo hediondo, de armadura espessa, prudente desertor ...

Para as lutas do amor, quero aprender contigo, quero fazer como fazes, animalejo frio, 
que tão calcariamente encouraçado, só sabes recuar ...

(Rosa, 1977:42-44, grifos nossos)

Portanto, o acréscimo dos culs-de-lampe em Tutaméia, considerada por ele como opera mea, será uma das marcas, o "sello" dos antigos poetas gregos marcando a autoria de seus poemas, e nessa ótica podemos ainda afirmar que tal intervenção gráfica está vinculada a quatro aspectos que permeiam a presença dos gregos em toda a obra de JGR: o significado da coruja e do caranguejo como "réplica" dos animais pintados nos escudos dos hoplitas na cerâmica grega (fig. 3 e 4); a vinculação da coruja à deusa Atena e aos seus predicados; a do caranguejo a Héracles e sua prova relativa a Hidra de Lerna; e a circularidade do tempo, expressa pela metáfora do alfabeto, onde as letras alfa e ômega, a primeira e a última do alfabeto grego, estão determinadas nos nomes: coruja e caranguejo, formando um quiasma.

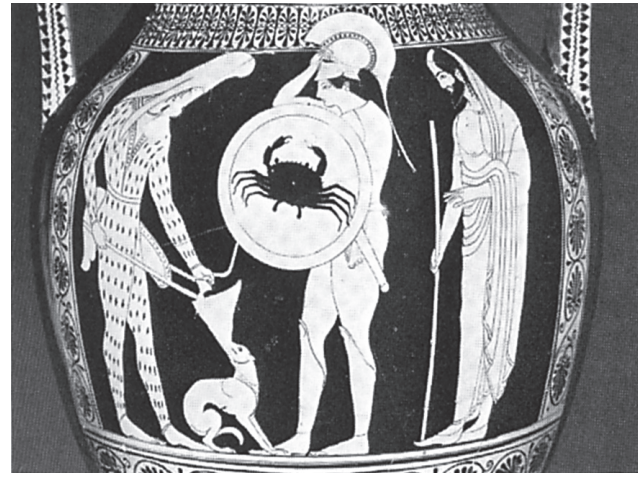

Fig. 3. Anfora de figuras vermelhas do pintor de Dikaios - Londres, Bristish Museum E 255, ARV,31,2. (apud Boardman, 1997: 45)

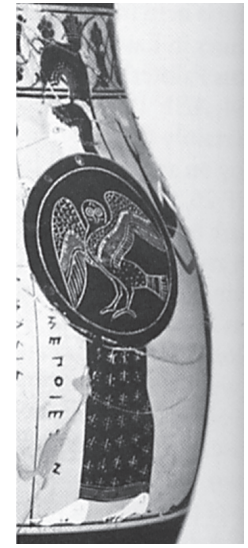

Fig. 4. Olpe de figuras negras do pintor de Amásis - Paris, Musée du Louvre Apud Bothmer, 1985:145)

E aqui poderíamos mais uma vez indagar: porque teria JGR intercalado a efígie desses dois animais ao final dos prefácios - Hipotrélico e Sobre a escova e a dúvida - e dos contos - Antiperipléia, Arroio-das-Antas, Barra da Vaca; Desenredo, Esses Lopes, Estoriinha, Faraó e a água do rio, Intruge-se, Grande Gedeão, Lá, nas campinas, Mechéu, No prosseguir, Os 
três homens e o boi dos três homens que inventaram um boi, Palhaço da boca verde, Quadrinho de estória, Rebimba, o bom, Ripuária, Se eu seria personagem, Sinhá Secada, Tresaventura, Uai, eu?, Umas formas, Vida ensinada, Zingaresca -, estando o intercalamento iniciado pela efígie da coruja e finalizado com a do caranguejo? Existe uma ordem no intercalamento das figuras? O fato de alguns contos e de dois prefácios, Aletria e Hermenêutica e Nós, os temulentos, não estarem assinalados pelos dois animais significa que eles estão fora do contexto significante das imagens ou que compõem um conjunto de contos, aos quais estão acrescidos os dois prefácios, que expressam um leque de sentidos abarcados pela imagem que encerra cada um desses conjuntos?

Em um esboço do conjunto dos contos e dos quatro prefácios teríamos o seguinte quadro:

\begin{tabular}{|c|c|}
\hline Coruja [*] & Caranguejo [४] \\
\hline $\begin{array}{l}\text { Aletria e Hermenêutica } 3 \text {-12 Prefácio } 1 \\
\text { Antiperipléia - 11-16 * }\end{array}$ & Arroio-das-Antas $17-20$ \\
\hline $\begin{array}{l}\text { A vela ao diabo } 21-23 \\
\text { Azo de almirante } 25-26 \\
\text { Barra da Vaca } 27-30\end{array}$ & $\begin{array}{l}\text { Como ataca a sucuri } 31-33 \\
\text { Curtamão } 34-37 \\
\text { Desenredo } 38-40\end{array}$ \\
\hline $\begin{array}{l}\text { Droenha } 41-44 \\
\text { Esses Lopes } 45-48 *\end{array}$ & $\begin{array}{l}\text { Estória } \mathrm{n}^{\circ} 349-52 \\
\text { Estoriinha } 53-56\end{array}$ \\
\hline Faraó e a água do rio $57-60 *$ & $\begin{array}{l}\text { Hiato } 61-63 \\
\text { Hipotrélico } 64-69 \bullet \text { Prefácio } 2\end{array}$ \\
\hline Intruge-se $70-73 \bullet$ & $\begin{array}{l}\text { João Porém, o criador de perus } 74-76 \\
\text { Grande Gedeão } 78-80\end{array}$ \\
\hline $\begin{array}{l}\text { Reminisção } 81-83 \\
\text { Lá, nas campinas } 84-87 *\end{array}$ & Mechéu $88-91$ \\
\hline $\begin{array}{l}\text { Melim-Meloso } 92 \text { - } 96 \\
\text { No prosseguir } 97 \text { - } 100 *\end{array}$ & $\begin{array}{l}\text { Nós, os temulentos } 101-104 \text { Prefácio } 3 \\
\text { O outro ou o outro } 105-107 \\
\text { Orientação } 108-110 \\
\text { Os três homens e o boi } 111-114\end{array}$ \\
\hline Palhaço da boca verde $115-118$ * & $\begin{array}{l}\text { Presepe } 119-121 \\
\text { Quadrinho de estória } 122-125 \\
\end{array}$ \\
\hline Rebimba, o bom $126-129 *$ & $\begin{array}{l}\text { Retrato de cavalo } 130-133 \\
\text { Ripuária } 134-137\end{array}$ \\
\hline Se eu seria personagem $138-141 *$ & Sinhá Secada $142-145 \bullet$ \\
\hline Sobre a escova e a dúvida 146-166 * Prefácio 4 & \begin{tabular}{|l|} 
Sota e Barla $167-170$ \\
Tapiiraiauara $171-173$ \\
Tresaventura $174-176$
\end{tabular} \\
\hline - Uai, eu? $177-179 *$ & Umas formas $180-183$ \\
\hline Vida ensinada $184-188 *$ & Zingaresca $189-192$ \\
\hline
\end{tabular}


Ora, um rápido exame da tabulação acima já nos mostra que a divisão foi feita a partir de uma relação estrutural entre os números 1, 2, 3 e 4, como se tivéssemos um jogo equilibrado entre os significados dos dois animais, $o$ que equivale ao reconhecimento de que uma resposta às questões acima formuladas exige uma volta ao contexto da cultura grega clássica, para nela determinarmos os significados atribuídos à coruja e ao caranguejo.

\section{Entre a sabedoria e a sofística: a coruja e o caranguejo}

A presença de animais na mitologia e na arte gregas pode ser constatada tanto na literatura quanto na iconografia, onde aparecem intimamente ligados à figura de deuses e heróis (Burkert, 1993:142-146; Sarian, 1987:1548). É assim, por exemplo, que Atena é assimilada à coruja, ao corvo e à serpente, Zeus à águia, Apolo ao falcão e ao cisne, tal como sugerido por Pistetero, em As Aves, 515-516, de Aristófanes,

Mas, o mais importante de tudo é que o próprio Zeus, que reina nos nossos dias, se perfila com uma águia sobre a cabeça, como rei que é. A filha usa uma coruja, e Apolo, como escudeiro, um falcão, ${ }^{12}$

enquanto nas pinturas da cerâmica grega aparecerão não apenas como emblema apotropaico nos escudos dos hoplitas (Chase,1902:61-68; 85-87; Pontin, 2006:258-259), mas, em várias outras situações, como, por exemplo, quando Atena é evocada pela presença da coruja sobre o forno do ceramista, velando dessa forma, pelo bom cozimento das peças (Sarian, 1993:105), e até mesmo quando da representação da cidade de Atenas na efígie da coruja cunhada nas moedas da Ática ou do caranguejo nas moedas da Magna Grécia (figs. 5, 6, e 7).

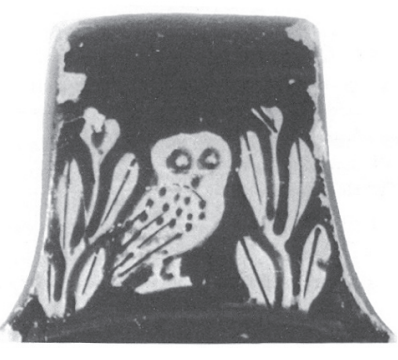

Fig. 5. Skýphos ateniense.

American School of Classical Studies at Athens.

${ }^{12}$ Cito aqui a tradução da Profa. Maria de Fátima Sousa e Silva. 


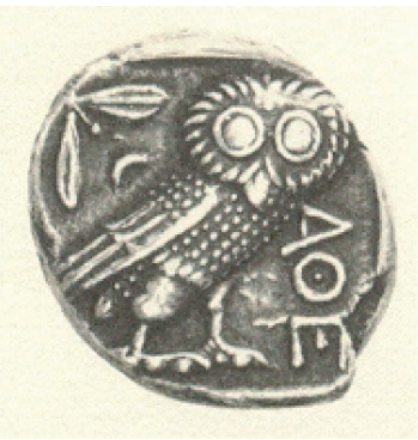

Fig. 6. Tetradracma ateniense.

American School of Classical Studies at Athens.

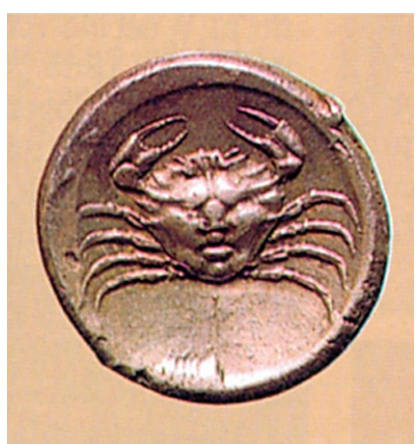

Fig. 7. Moeda de Agrigento Museu Regional de Agrigento.

Mas os deuses estão também associados à proteção dos heróis, e, nesse sentido, Atena é a deusa que protege Héracles da perseguição de Hera, um herói que como assinala W.Burkert "é o maior dos heróis gregos", sendo, simultaneamente, herói e deus, envolvido por um mito de "atmosfera trágica, heróica e humana" que está "relacionado antes de mais com os animais" (Burkert, 1993:405-406) e que, acreditamos, estão por trás do valor iconográfico atribuído por JGR às efígies da coruja e do caranguejo.

\subsection{A coruja e a philosophía}

O valor iconográfico da coruja aponta para os predicados da deusa Atena, seu olhar glaukópis, seus olhos brilhantes, penetrantes, terríveis, seus "olhos de coruja" (Chantraine,1968:226; Douglas, 1912:174-178; Lawler, 1939:493-494; Pottier,1908:529-548; Meillier, 1970:5-30) que vêem com acuidade, ave noctua, que vê no escuro, denotando parte da sophía da deusa protetora dos artesãos, e que, segundo Platão, no Crítias, 109b-13 e 109c6-10, juntamente com Hefesto, recebeu a Ática como lote, na divisão feita pelos deuses da terra inteira, por ser identificada com a philosophía e a philotekhnía e por ser esse lote o mais "naturalmente familiar a phrónesis e a areté povoaram-na de homens bons feitos de modo autóctone, e que com o noûs organizaram a politeía".

E aqui vale observar que nos Cadernos Homero (cf. martins costa, 2002:97-98; 113-116) Rosa faz mais de uma anotação sobre o epíteto de Atena: 
5. tão terrível era o brilhar dos olhos de Pallas Athenéa - Achilles aí a reconheceu.

6. "Athene of the Flashing eyes".

91. "bright-eyed Athene"(glaukópis)

$[\ldots]$

ILIAS

$[\ldots]$

"Pallas Athene gewaltig leuchtende Augen"[...]

"Athene, die Goettin mit Leuchtenden Augem (glaukópis)

"die Helläugige = Athene

Entretanto, Atena, filha de Zeus e Métis, nascida do cérebro de Zeus, já vestida com a égide e entoando um canto de guerra, é deusa violenta que acompanha os guerreiros na luta e na guerra, e que quando veste a égide aterroriza os inimigos, paralizando-os, e, como observa Burkert, ao enumerar os "mitos sinistros" que a ela estão vinculados, a "aígis, como diz o nome, é uma pele de cabra" (...), que de fato era "um monstro, uma gorgô, que a própria Atena matou e esfolou" (Burkert, 1993:280), mas, ao lado dessa via guerreia, Atena, é também deusa protetora dos artesãos, da tecelagem, inventou o carro de guerra, a quadriga, e ajudou na construção do primeiro navio; protege as oliveiras tendo, também, inventado o azeite.

Assim, o vigor do olhar de Atenas, sua participação no poder e na phrónesis que lhe advém de Zeus e Métis, no mito de seu nascimento já enfatizado por Hesíodo na Teogonia e por Pindaro, na Olímpica VIII, será explicada por Sócrates a Hermógenes, no Crátilo, a partir de uma visão onde a phrónesis é privilegiada em detrimento da versão mais antiga,

S: Nós chamamos-lhe Palas. Não é assim?

H: Sem dúvida.

S: Ora, supondo que esse nome deriva da dança das armas, nós faríamos, creio eu, uma suposição reta; porque erguer-se a si mesmo da terra ou a outra coisa qualquer, por meio das mãos, a isto chamamos pállein e pállesthai, dar movimento de dançar e dançar.

$\mathrm{H}$ : Exatamente.

$[\ldots]$

H: Perfeitamente. E, quanto ao outro nome, que te parece? 
$\mathrm{S}: O$ de Athena? [...]

S: Esse é coisa mais séria, amigo. Creio que os antigos já pensavam de Atena, como hoje os versados em poesia homérica. A maioria deles, ao explicarem o poeta, afirmam que este equiparara Athena à própria inteligência e ao pensamento (autòn noûn kaì diánoian), o que parece ser também a maneira de ver do autor dos nomes, o qual, designando mais explicitamente theou nóêsin, assevera, ademais, que ela é, por assim dizer, há theonóa, empregando a em vez de ê, como fazem os estrangeiros, e suprimindo i e s. Pode ser, porém, que não seja ainda esta a explicação e que a chamasse Theonóe, na convicção de que ela compreende as coisas divinas melhor do que outrem. Além disso, não se exclui que ao seu éthos inteligível (éthei néesin) desse o nome de Ethonóe, julgando que essa era igual a nossa deusa - nome que transformado em uma forma mais bela, como o seu autor ou outros posteriores julgavam, passou, depois, a ser Athenaa.

$(\text { Cra., } 407 \mathrm{a}-\mathrm{b})^{13}$

Desse modo, quando Rosa acrescenta a imagem da coruja ao final dos prefácios e contos acima mencionados, está, cremos, posicionando todo esse "éthos inteligível", à compreensão de seus prefácios e contos, delimitando sua reflexão acerca da condição e da natureza humanas a partir do testemunho dos olhos tão bem articulados nas imagens oftalmológicas da capa de Tutaméia (fig.8), na edição da José Olympio e já delimitado pelo poema que entremeia a prosa de Aletria e Hermenêutica (Rosa, 1967:7):

${ }^{13}$ Tradução do Pe. Manuel Dias Palmeira, com modificações. 
"Comprei uns óculos novos, óculos dos mais excelentes: não têm aros, não têm asas, não têm grau e não têm lentes."

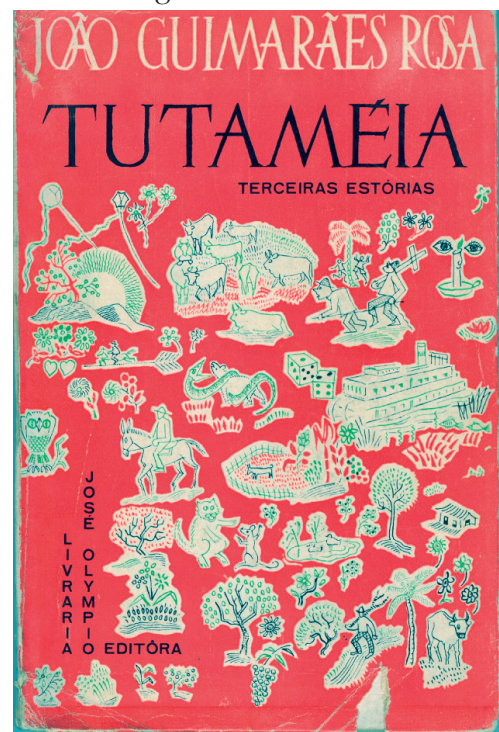

Fig. 8. Capa da $1^{\mathrm{a}}$. edição de Tutaméia, de Luís Jardim a partir das indicações feitas JGR.

Aos olhos por detrás das velas, aos olhos glaukópis da coruja, aos olhos do gato diante do rato e ao olhar silencioso do boi nos desenhos da capa, estaria Rosa acrescentando, a partir do poema que parafrasea a quadra de Apporelly, "citada de memória", e de sua conclusão de que a "vida também é para ser lida", a versão platônica do conhecimento como o movimento dos olhos na leitura dos dois manuscritos acerca da emergência da justiça na cidade e na alma dos homens? Não estaria ele ratificando a hierarquia das imagens da narrativa da caverna platônica, também citada em Aletria e Hermenêutica: "A vida também é para ser lida. Não literalmente, mas em seu supra-senso. E a gente, por enquanto, só a lê por tortas linhas. Está-se a achar que se ri. Veja-se Platão, que nos dá o 'Mito da Caverna' "? Esses óculos que não têm aros, não têm asas, não têm grau e não têm lentes, não seriam os óculos da diánoia, os olhos do pensamento, que nos fazem enxergar com acuidade, quando a visão dos olhos tende a perder a sua força, como diz Sócrates a Alcibíades no final do Banquete de Platão (cf. Smp., 219a2)? 
"Em casa de caranguejo, pele fina é maldição": Filosofia

e Sofística em Tutaméia de João Guimarães Rosa

\subsection{O caranguejo e a sofística}

Quando nos voltamos para a figura de Héracles vemos que ela não terá menos importância: primeiro pela mencionada ligação com Atena, segundo por seu valor exemplar na dor e no sofrimento como marcas da condição humana e que estão assinaladas na tradição de suas doze provas (Lopes, 2004), cuja superação, alçou-o ao mundo dos deuses. Entre essas provas, a segunda, aquela que envolve o combate à Hidra, criada no pântano de Lerna, que tinha um corpo imenso, com nove cabeças, oito mortais e a nona, que ficava no meio das cabeças, imortal, e que com seu sopro envenenado devastava os campos e devorava os rebanhos. Héracles, montado em um carro conduzido por Iolau, chegou a Lerna e ao descobrir a Hidra em uma colina, obrigou-a a sair atingindo-a com suas flechas envenenadas, e embora a tivesse dominado, de nada adiantava abater suas cabeças, porque onde cortava uma, nascia duas. Um enorme caranguejo que ajudava a Hidra mordendo o pé de Héracles foi morto por ele, com a ajuda de Iolau, que tendo incendiado um bosque vizinho, possibilitou a Héracles valer-se das brasas em chamas para queimar as cabeças que renasciam, até chegar à cabeça imortal que foi por ele decepada (Apollod., Biblioteca, II, 5).

Ora, é essa mesma narrativa sobre a segunda prova de Héracles que vamos encontrar, na caderneta 7, datada de 1962/1963, e pertencente ao Arquivo JGR do IEB/USP, clarificando e renovando a figura do "feiíssimo caranguejo à frente do escudo lamacento do velho hoplita": ${ }^{14}$

m\%-Cammerino ou Averno

m\% - Camerino ou Averno

CAMERINO ou CAMARINO = famoso brejo da Sicília, cujas águas exalavam horrivel fedor. O oráculo de Apolo respondeu ao povo que [...] não deviam dessecá-lo. Os Sicilianos não entenderam, e o dessecaram, facilitando por ali a entrada de seus inimigos, que saquearam a ilha.

AVERNO ou ARNO, brejo da Campânha, consagrado a Plutão, e com exalações tão infectas, que pensava-se ser a ali a entrada dos infernos. Os pássaros que o sobrevoavam caíam mortos nêle.

${ }^{14}$ A menção ao caranguejo no "lamacento" escudo do velho hoplita poderia permitir-nos inferir que as provas de Héracles, e a presença do caranguejo enviado por Hera para morder o pé de Héracles, já estavam no horizonte de JGR? Os grifos são nossos. 
$m \%$ - (brejo) fedor camerino ou averno

LAVERNE = divindade que presidia aos furtos e protegia os ladrões. Era representada pela figura de um homem sem cabeça.

(LAVERNA - ?)

LERNA = brejo no território de Argos, onde estava a hidra policéfala, que Hércules destruiu. E onde as Danaides jogaram as cabeças de seus maridos.

CANCER OU CARANGUEJO = foi o animal que Juno enviou contra Hércules, quando êle combatia a hidra do brejo de Lerna. O caranguejo mordeu o pé de Hércules, mas êste o matou, e Juno o pôs no número dos 12 signos do Zodíaco.

(Caderneta 7, p.91, datada de 10/11/1062 a 12/01/1963, grifo nosso) ${ }^{15}$

Visto sob esse enfoque, não nos surpreenderá que no Eutidemo, "um dos mais instigantes diálogos de Platão", nas palavras de J. L. Brandão (Brandão, 1988:32), encontremos Sócrates, tal como Héracles no pântano de Lerna, confrontando a "Hidra da Sofística" (Eutidemo, 297b-e).

A esse confronto, entre o "método de inquérito socrático com o método ou os métodos sofísticos", para não só separá-los, mas, também, para fazer a defesa de Sócrates, e "salvar a filosofia" (Brandão, 1988:3233), poderíamos acrescentar que por trás da crítica platônica subjaz a concepção de dialética já exposta no Mênon e retomada na República, de que o "diálogo" em seu estatuto filosófico é um procedimento que supõe como condição necessária a philía e o saber (eidénai) acerca do sentido dos nomes (cf. Mênon, 74b), o que implica no reconhecimento de que a dialética platônica traz nela embutida uma concepção de diálogo que envolve uma "homología", um acordo acerca do sentido das palavras, diferenciando-se da erística por seu valor político e filosófico, se entendermos esse valor nos termos em que são apresentados no contexto da República.

A erística exercitada pelos dois "novos sofistas", Eutidemo e Dionisodoro - tal como é narrada por Sócrates a Críton, quando este indaga acerca da conversa que travou no dia anterior, no Liceu, quando se encontrou com eles e com Clínias e Ctésipo, acerca da "sophía" que diziam possuir e de como eram hábeis no ensino da areté -, não é capaz de dialogar, é surda e solitária, pois, o "diálogo" (pensado na versão platônica) comporta o "pseûdos" e o "engano", de modo que quando afirmamos 'algo', esse

${ }^{15}$ Caderneta 7 pertencente ao IEB/USP. 
'algo'deve aderir ao critério de verdade expresso pelo que é o justo, daí a analogia de Sócrates com Héracles, pois tão nefasta quanto a Hidra de Lerna é a afirmativa de Eutidemo de que é possível saber "como os homens bons, são injustos" (Euthd., 296e): ${ }^{16}$

E tu, Eutidemo, voltei a falar, que me dizes? Achas que não falou certo teu irmão que tudo sabe?

Serei irmão de Eutidemo? Apressou-se a dizer Dionisodoro.

Ao que repliquei: Deixa isso, caro amigo, para depois que Eutidemo me ensinar como é que eu sei que as pessoas honestas são injustas. Não me invejes esta oportunidade de aprender.

Esquivas-te, Sócrates, disse Dionisodoro, e não queres responder.

É natural, lhe objetei; sendo como eu sou, inferior a cada um de vós, isoladamente considerado, não é fazer figura feia e pôr-me em fuga diante dos dois. Sou muito mais fraco do que Héracles, que não foi capaz de lutar sozinho contra a Hidra, a tal sofista que tinha a habilidade, sempre que alguém cortava uma cabeça ao seu discurso, de fazer nascer muitas outras no lugar da primeira, e, ao mesmo tempo, contra outro sofista, certo caranguejo que, ao meu parecer, chegara do lado do mar e acabara de desembarcar. E como este, postado à sua esquerda, começasse a incomodálo, a falar e a mordê-lo, gritou por socorro para seu sobrinho Iolau, que de fato o ajudou bastante naquela conjuntura. Mas se o meu Iolau, que se chama Pátroclo, interferisse agora, pior eu ficaria do que antes.

Então, me responde disse Dionisodoro, uma vez que tu mesmo nos contaste essa história, se Iolau era mais sobrinho de Héracles do que de ti? (Euthd., 297b-d, grifos nossos)

A "sophía-total" de Eutidemo e Dionisodoro que afirma ensinar a excelência (aretế) e ser possuidora de saberes acerca de todas as formas de combate, do pancrácio a hoplomakhía, ensinando tudo o que é necessário para a formação de um bom estratégo e também a "falar e a escrever discursos" que levam a vitória nos Tribunais, parece, entretanto, quando se trata de "conhecer" o que é, restringir seu discurso à afirmação da impossibilidade de dizermos o psê̂dos, e nesse sentido, o lógos pode tudo, pois tudo o que é, está a ele subscrito, não importando assim, se ele diz o justo.

16 Tradução de Carlos Alberto Nunes, com modificações. 
Ora, se nos voltarmos para Tutaméia e para seu primeiro prefácio, Aletria e Hemenêutica, veremos que Rosa não duvida, entre o filosófo e o sofista, entre Protágoras e Sócrates, entre a impossibilidade de se dizer o pseûdos e a possibilidade do mythos, escolherá o "diálogo platônico" como o contexto possível para se captar as "malhas do incognoscível" (Rosa, 1967:5):

"Sintetiza em si, porém, próprio geral, o mecanismo dos mitos - sua formulação sensificadora e concretizante, de malhas para captar o incognoscível - a maneira de um sujeito procurar explicar o que é o telégrafo-sem-fio:

- "Imagine um cachorro basset, tão comprido, que a cabeça está no Rio e ponta do rabo em Minas. Se se belisca a ponta do rabo, em Minas, a cabeça, no Rio, pega a latir..."

- "E é isso telégrafo-sem-fio?

- "Não. Isso é o telégrafo com fio. O sem-fio é a mesma coisa ... mas sem o corpo do cachorro."

[...].

"O erro não existe: pois que enganar-se seria pensar ou dizer o que não é, isto é: não pensar nada ou não dizer nada". - proclama genial Protágoras; nisto, Platão é do contra, querendo que o erro seja coisa positiva; aqui, porém, sejamos amigos de Platão, mas ainda mais amigos da verdade; pela qual, aliás, diga-se, luta-se ainda e muito, no pensamento grego." (Rosa, 1967:5,9. grifos nossos)

Ora, a escolha pelo circunlóquio do riso não é, também, uma outra versão platonizante do texto de Rosa? Os prefácios não marcariam esse antigo combate contra a Hidra da Sofística, cheia de "tento ou cento hipotrélicos" cujos sentidos vêm expressos pela efígie do caranguejo ao final do prefácio intitulado Hipotrélico? À solidão dialógica de "Nós, os temulentos" expressa no roteiro transmutado de Chico, o herói, que afligido "pela corriqueira problemática quotidiana, a qual tentava, sempre que possível converter em irrealidade, (...) a pifar, virar e andar, de bar a bar", não atrelou Rosa um novo par de óculos reduplicador de imagens de si mesmo, nas imagens de Chico diante do espelho do velho armário?

$E$, avançando contra o armário, e vendo o outro arremeter também ao seu encontro, assestou-lhe uma sapatada, que rebentou com o espelho nos mil 
pedaços de praxe.

- Desculpe, meu velho. Também, quem mandou você não tirar os óculos? (ROSA, 1967:104)

Daí que no quarto prefácio, escorado na efígie da coruja, poderá afirmar "empiricamente" entre Sextus e Proust que "tudo é incauto e pseudo, as flores sou eu não meditando, mesmo o de hoje é um dia que comprei fiado" (Rosa, 1967:151), que "haveria uma verdade aparentemente inventada - a da ficção - parecendo independente da histórica, mas, de fato, verdade histórica, a qual solta no ar - no ar psíquico - a sensibilidade ou a imaginação de algum novelista, mais concentrado na sua procura de assunto e de personagens, a apreendesse por um processo metapsíquico ainda desconhecido", pois, além, o "mundo supura é só a olhos impuros", e enquanto Deus está fazendo coisas fabulosas", podemos indagar: "para onde nos atrai o azul?" A resposta, que não nos parecer ser difícil de encontrar, pode ser também platônica, isto é, aquela que nos torna disponíveis à elaboração de uma teoria da alma.(Rosa, 1967:167)

Assim, os sentidos atrelados por Rosa ao termo 'tutaméia' - nonada, baga, ninha, ossos-de-borboleta, quiquiriqui, tuta-e-meia, mexinflório, chorumela, nica, quase-nada; mea omnia - não nos colocariam nesse intervalo entre a suspensão do juízo e a contemplação das idéias? Não é nesse intervalo que a "boa escritura" se constitui?

E se em "Platão está tudo", uma leitura platonizante de Tutaméia, contribui para uma melhor compreensão, não somente do vigor da obra rosiana, mas, também, para uma mais legítima valoração da participação dos clássicos gregos na formação da cultura brasileira, com certeza, a "moça grega" que Rosa encontrou em Paris, em 1949, ${ }^{17}$ estava com toda razão quando assim o classificou: "Ah mon ami, vous êtes platonicien!"

\section{Referências Bibliográficas}

American School Of Classical Studies At Athens. (1959), Pots and Pans of Classical Athens. Athens.

American School Of Classical Studies At Athens. (1994), Life, death and litigation in the athenian agora. Athens.

${ }^{17}$ Diário em Paris, datado de 25-30 de setembro-1-3 de outubro 1949. 
Apollodorus (1995), The Library. Translation by J. G. Frazer. Cambridge,

Massachussets, Harvard University Press (Loeb Classical Library, 121).

Aristófanes (1989), As Aves. Tradução, introdução e notas de Maria de

Fátima Sousa e Silva. Lisboa, Edições 70.

Bizzarri, E. (2003, 3. . ed.), João Guimarães Rosa - Correspondência com seu tradutor italiano. Rio de Janeiro, Belo Horizonte, Ed. Nova Fronteira, Editora da UFMG.

Boardman, J. (1997), Athenian red figures vases. London, Thames and Hudson.

Bothmer, D. (1985), The Amasis painter and his world-Vase-painting in sixth-century B.C. Athens. Malibu, London, The P.Getty Museum, Thames and Hudson.

Brandão, J. L. (1998), "O jogo e o labirinto no Eutidemo". Revista Filosófica Brasileira 4(3):23-50.

BURKERT, W. (1993), Religião grega na época clássica e arcaica. Tradução de M. J. Simões. Lisboa, Fundação Calouste Gulbenkian.

Burkert, W. (1998) Héraclès et les animaux. Perspectives préhistoriques et pressions historiques. Bonnet, C., Jourdain-Annequin, C. et PireneDeforge, V. (eds.), Le bestiaire d' Héraclès. III e. Recontre héraclenne. Kernos, suplemment 7, Liège, Centre International d'Études de la Religion Grecque.

Chantraine, P. (1990), Dictionnaire Étymologique de la Langue Grecque, Paris, Klincksieck, 2 vol.

Chase, G. H. (1902), "The shield devices of the Greeks". Harvard Studies in Classical Philology 13:61-127.

Correa, P. C. (2003), Harmonia. Mito e música na Grécia antiga. São Paulo, Humanitas FFLCH/USP.

Douglas, E. M. (1912), "The owl of Athena". Journal of Hellenic Studies 32:174-178.

Dumont, J. (2001), Les animaux dans l'Antiquité Grecque. Paris, Le Hamarttan.

Frère, J. (1998), Le bestiaire de Platon. Paris, Éditions Kimé.

Giovanni, G. (s.d), Agrigento-Il Valle dei templi \& il Museo regionali. Agrigento, Edizioni di Giovanni.

JACKSON, R. (1990), "Socrates' Iolaos: myth and eristic in Plato's Euthydemus". CQ 40 (2):378-395. 
Johnson, F. P. (1995), "A note on owl skyphoi". American Journal of Archaeology 59 (2):119-124.

LAwleR, L. B. (1939), "The dance of the owl and its significance in the history of Greek religion". Transactions and Proceedings of the American Philological Association 70:482-502.

Livraria José Olympio Editora (1968), Em memória de João Guimarães Rosa. Rio de Janeiro, Livraria J. Olympio Editora.

Lopes, A. O. D. (2003-2004), "Héracles na Ilíada". Kléos 7-8:11-54.

Martins Costa, A. L. (1997), "Poty, parceiro de Rosa". Livros 10: 1.

Martins Costa, A. L. (2001-2002), "Homero no Grande Sertão". Kléos 5-6:79-124.

Martins Costa, A. L. (2002), Guimarães Rosa, viator. Rio de Janeiro, UERJ/ABL, 2002. (Tese de Doutorado).

Martins Costa, A. L. (2006), "Veredas de Viator". Cadernos de Literatura Brasileira do IMS 10 (21-22): 10-58. (Edição especial comemorativa dos 10 anos dos Cadernos de Literatura Brasileira).

Martins Costa, A. L. (2006), "Via e viagens : a elaboração de Corpo de Baile e GSV". Cadernos de Literatura Brasileira do IMS, 10(21-22):187235. (Edição especial comemorativa dos 10 anos dos Cadernos de Literatura Brasileira).

Meillier, C. (1970), "La chouette et Athéna". Revue des Études Anciennes. Bordeaux 72 (1-2):5-30.

Moraes Augusto, M. G. (2004), Entre os prazeres e os deveres do lógos: gênero e retórica no Livro I da República de Platão. I Colóquio Platônico: Politeía, I. Rio de Janeiro, PRAGMA, UFRJ.

Nunes, B. (1958), Benedito Nunes relata sua conversa com Guimarães Rosa por ocasião do lançamento de Tutaméia. Suplemento Literário do jornal Minas Gerais, 23 de nov.:1-3.

Nunes, B. (1976), O dorso do tigre. 2a. ed. São Paulo, Perspectiva.

Nunes, B. (2006), "O autor quase de cor: rememorações filosóficas e literárias". Cadernos de Literatura Brasileira do IMS 10 (21-22):236244. (Edição especial comemorativa dos 10 anos dos Cadernos de Literatura Brasileira).

Platon (1975), Les Lois. Texte établi et traduit par É. des Places. Paris, Les Belles Lettres. t. 11-12.

Platão (1980), As Leis. Tradução e notas de Carlos Alberto Nunes. Belém, Ed. Universidade do Pará. 
Platon (1983), Phèdre. Texte établi et traduit par Leon Robin. Paris, Les Belles Lettres.

Platão (1978), Fedro. Tradução e notas de Carlos Alberto Nunes. Belém, Ed. Universidade do Pará.

Platão (1963), Crátilo. Versão do grego, prefácio e notas pelo Pe. Dias

Palmeira. Lisboa, Sá da Costa.

Platon (1978), Philèbe. Texte établi et traduit par Auguste Diès. Paris, Les

Belles Lettres.

Platon (1989), Le Banquet. Notice de Leon Robin, texte établi et traduit par Paul Vicaire. Paris, Les Belles Lettres.

Platon (1970), Timée - Critias. Texte établi et traduit par Albert Rivaud.

Paris, Les Belles Lettres.

Platon (1980), La République. Texte établi et traduit par Émile Chambry.

Paris, Les Belles Lettres. 3v.

Pollard, J. (1975), Birds in Greek life. London, Thames and Hudson.

Pontin, P. B. do V. (2005-2006), O escudo grego: a simbologia de um equipamento defensivo. São Paulo, MAE/USP. (Tese de Doutorado).

Pottier, E. (1908), "La chouette d'Athéné", Bulletin de Correspondence Hellenique 32:529-548.

Rosa, J. G. (1953), Diário em Paris. Letras e Artes, domingo, 17 de maio: 2. Rosa, J. G. (1956), Corpo de Baile. Rio de Janeiro, Livraria José Olympio Editora, $2 \mathrm{v}$.

Rosa, J. G. (1958), "Duas cartas inéditas". Cavalo Azul 3:31.

Rosa, J. G. (1957), Tutaméia. Rio de Janeiro, Livraria José Olympio Editora.

Rosa, J. G. (1968), O verbo \& o logos. Em memória de João Guimarães Rosa. Rio de Janeiro, Livraria José Olympio Editora:55-87. (Discurso de posse na Academia Brasileira de Letras, em 16 de novembro de 1967).

SARIAN, H. (1985), "A expressão imagética do mito e da religião nos vasos gregos e na tradição grega". Brandão, L.L. \& Pinto, N.F. Cultura Clássica em Debate. Belo Horizonte, UFMG/CNPq/SBEC.

Sarian, H. (1989), "Poieîn-Gráphein: o estatuto social do artesão-artista de vasos áticos". Revista do Museu de Arqueologia e Etnologia 3:105120.

Tschichold, J. (2007), A forma do livro. Ensaios sobre tipografia e estética do livro. Tradução de José Laurêncio de Melo. São Paulo, Ateliê Editorial. 